\title{
The Effect of VCO Processing Method on Blood Glucose, Cholesterol and Pancreatic Profile of Diabetic Mellitus Rats (Sprague Dawley)
}

\author{
Pengaruh Metode Pengolahan VCO terhadap Glukosa Darah, Kolesterol dan Profil \\ Pankreas Tikus Diabetes Melitus (Sprague dawley)
}

\author{
Dadang Supriatnaa, Amilia Dayatri Urayb, Made Astawanc, \\ Deddy Muchtadic and Tutik Wresdiyatib \\ ${ }^{a}$ Center for Agro-Based Industry (CABI), Agency for Industrial Research and Development, Ministry of Industry, \\ Jl. Ir. H. Juanda No. 11, Bogor Indonesia \\ ${ }^{b}$ Faculty of Veterinary, Bogor Agricultural University, \\ Campus IPB Dramaga, Bogor Indonesia \\ cFaculty of Agricultural Technology, Bogor Agricultural University, \\ Campus IPB Dramaga, Bogor Indonesia
}

diazarapapa@yahoo.co.id and tutikwr@gmail.com

Riwayat Naskah:

Diterima 05, 2018 Direvisi 07, 2018 Disetujui 11, 2018
ABSTRAK: Virgin Cococnut Oil (VCO) dengan nama produk sesuai SNI Minyak kelapa Virgin, hubungannya dengan manfaat kesehatan, diproduksi dengan berbagai cara. Tujuan penelitian adalah untuk mempelajari metode proses pemngolahan VCO terhadap manfaat kesehatan dalam menurunkan kadar gula darah, profil kolesterol dan jaringan pankreas pada tikus Sprague dawley penderita Diabetes Melitus (DM). Empat group dari lima group tikus diinjeksi alloxan untuk membuat tikus tersebut sakit DM, sementara itu satu group dijadikan kontrol negatif (tikus sehat). Tiga group dari lima group tikus tersebut dicekok dengan masing-masing VCO-A yang diproduksi tanpa panas, VCO-B yang diproduksi dengan panas terkendali, serta minyak goreng kelapa atau Coconut Cooking Oil (RBD CNO) yang diproduksi menggunakan panas tinggi dan kimiawi, sementara 2 group lainnya dicekok dengan air sebagai kontrol negatif (tikus sehat) dan kontrol positif (tikus DM). Dalam 28 hari pengamatan semua tikus diperiksa kadar gula darahnya, dan diakhir hari pengamatan semua tikus di bedah untuk mencek kolesterol dan profil jaringan pankreasnya. VCO-A secara positif signifikan mengurangi kadar glukosa darah dinading yang lainnya. VCO tidak mempengaruhi kadar kolesterol dan menghambat kerusakan sel $\beta$ pancreas dari tikus DM. Dalam 28 hari pengamatan semua perlakuan VCO dapat mengurangi kadar glukosa darah tikus DM.

Kata kunci: metode pengolahan VCO, diabetes mellitus, gula darah, jaringan pankreas

ABSTRACT: Virgin Coconut Oil (VCO) can be produced by different methods related to health function. The objective was to study the efficacy of VCO processing method in reducing blood glucose level, cholesterol profile and pancreatic tissue profile of diabetic mellitus (DM) Sprague dawley rats. Four rat groups from five rat groups were injected using alloxan to induce the diabetic condition, while the rest was negative control. VCO-A produced without heat and VCO-B produced with controlled-heat treatment and Coconut Cooking Oil (RBDCNO) produced with the application of severe heating and chemical (MG) were fed respectively to three rat groups, while the other two rat groups were fed by water and used as negative control (healthy rats) and positive control (DM rats). During 28 days observation, all of the rats blood glucose level were assessed, and at the end of the observation day the rats were terminated to assess the cholesterol and pancreatic tissues profile. VCO-A significantly positive reduced blood glucose level than the others. VCO did not influence DM rats cholesterol profile and all VCO inhibits the rate of pancreatic $\beta$ cells damage. On 28 days observation all VCO treatments suppressed blood glucose level of DM rats.

Keywords: processing method of virgin coconut oil, diabetes mellitus, blood glucose, pancreatic tissues 


\section{Introduction}

Virgin Coconut Oil (VCO) is one of value added products produced from coconut meat, which has higher economic value than coconut cooking oil. In the domestic and international market the price of VCO has a sale value of 10 to 20 times than the price of coconut cooking oil. This attractive price is due to the health benefits of VCO for human, such as for body health care, cosmetics and spa industries.

Rindengan and Novarianto (2005), stated that there are various methods of manufacturing VCO i.e. the changing of the emulsion form of coconut milk, fermentation, enzymatic, centrifugations, direct heating, and the Intermediate Moisture Content (IMC) methods (Supriatna, et.al., 2000).

Virgin Fats and Oils means edible vegetable fats and oils obtained by mechanical procedures and the application of heat only, they may have been purified by washing with water settling, filtering and centrifuging (Codex, 2001). Based on these descriptions, VCO made by heat application without any chemicals for purification.

The Lauric acid of VCO, as bioactive compound, will be metabolized into monolaurin in the body which is effective to kill germs of viruses, bacteria, fungi and protozoa (Enig, 1996). The VCO reduce the levels of HIV / AIDS in the blood of patients (Dayrit 2005). VCO was also reported not to cause heart problems in Kerala study (Rethinam et al, 2005). Medium chain fatty acids in coconut oil are similar to the fatty acids of breast milk, and VCO can be used to help in degenerative diseases treatment such as atherosclerosis, diabetes, cancer, obesity, stroke and others (Kabara, 2000).

Among various degenerative diseases, diabetes may cause complications, such as renal disease, cardiac disorders, gastrointestinal disorders, blood vessel blockage, decay and leg amputations, blindness, erectile dysfunction, disturbances of touch sensitivity (numbness), pain throughout the body, and death (Wibowo, 2005).

VCO may prevent complications of diabetes mellitus by inducing insulin secretion in the diabetics as VCO is easily absorbed. Inside the body, the lauric acid and capric acid of VCO, , stimulates the secretion of insulin by Langerhans cells of the pancreas (Garfinkel et al, 1992).

According to the International Diabetes Federation (IDF) there are approximately 177 million people worldwide suffered from diabetes, and mostly type-2 diabetes (Anon, 2006), and WHO predicts it may increase up to 300 million people in the next 25 years.

This research was conducted to find out the health benefits of VCO, especially for diabetes mellitus, and to find out scientific evidence on efficacy of VCO produced with and no-heat well as low heat treatments, especially on the the efficacy medium chain saturated fatty acids (C6-C12) in VCO in lowering blood glucose levels of diabetes mellitus in rodent model.

Based on the above description, research problems are formulated as follows: Does the processing method of VCO affect the activity bioactive compound of medium chain saturated fatty acid on decreasing blood glucose levels, affecting the cholesterol value and pancreatic tissue profile of diabetes mellitus rats.

\section{Materials and Methods}

\subsection{Materials}

The materials consisted of VCO, coconut cooking oil, male Sprague Dawley rats, rats feed, and chemicals. Two types of VCO, VCO-A is the VCO which is processed without heat (VA) and bought from VCO supplier in Bogor, and VCO-B is the VCO which is processed using the controlled heat (VB) and made in CABI. Meanwhile, the commercially branded coconut cooking oil (MG) represents the coconut oil processed using high heat and chemical purification and purchased from a supermarket in Bogor.

Sprague Dawley male rats with body weight ranging from 150 to 250 grams, were purchased from "Langit Biru" a breeder rats at Taman Kencana Bogor. The materials for the rat feed formulation were purchased from a supermarket in Bogor, and the Chemistry Stores in Bogor. Alloxan for inducing rats into diabetes mellitus was ordered from Singapore. The chemical substances for chemical analysis such as monochloride iodine, acetic acid, siclo-hexan, $20 \%$ potassium iodide, sodium thiosulfate $0.1 \mathrm{~N}$, Wijs solution, 95\% neutral alcohol, $\mathrm{NaOH}, \mathrm{KOH}$, phenolftalein $0.5 \%$, chloroform, $\mathrm{HgO}$ crystals, helium, hydrogen, BF-3 Methanol, petroleum ether p.a. were obtained from CABI. Chemical substances for treatment of rats pancreatic organs such as Bouin solution, a solution of dehydration (alcohol 70\%, alcohol 80\%, alcohol 90\%, alcohol 95\% and absolute alcohol), xylol, haematoxylin, eosin, antibody monoclonal insulin (Sigma I2018), PBS, diaminobenzidine, normal serum, $\mathrm{H}_{2} \mathrm{O}_{2}$, methanol, distilled water (DW), conjugated antibodies, paraffin, adhesive, neofrendan etc. were obtained from the Histological Laboratory Veterinary Faculty of Bogor Agricultural University.

\subsection{Methods}

Based on field observations, the VCO-A was made by centrifuge technology without any heat application. 
VCO-B (VB) was produced by CABI using the Intermediate Moisture Content (IMC) technology without going through coconut milk step. In IMC technology VCO obtained from fresh grated coconut meat which is dried directly using artificial drying method with controlled temperature at $60^{\circ} \mathrm{C}$ prior to pressing.

The coconut cooking oil used in the study was commercially branded coconut cooking oil in the market. Based on field observations, the coconut cooking oil production is carried out through the process by pressing copra and then the oil obtained is purified in a special purification plants using high heat and chemicals.

\subsubsection{Animal experiment}

Before starting the research, all Sprague Dawley rats were subjected to an adaptation period for 6 days, and were observed for their health condition and fed with basic feed and water on ad libitum.

After going through a period of adaptation, the rats were fasted for 1 night, and then injected intravenously with alloxan $(110 \mathrm{mg} / \mathrm{kg}$ of rat body weight) . After 2 days, their serum glucose level was measured by using glucometer. The rats with serum glucose levels more than $200 \mathrm{mg} / \mathrm{dl}$ categorized as suffered from diabetic mellitus, and then classified to 4 groups $(\mathrm{n}=5)$. The groups consisted of positive control (K+), VA, VB and MG, in addition, one group of healthy rats $(n=5)$ was not injected with alloxan, as a negative control group (K-).

All 5 groups of rat were fed with basic feed and drinking water every day ad libitum. In addition, VCO and coconut cooking oil were administered orally to each group of the rats every day, respectively for 28 days. The dose of VCO or coconut cooking oil was $0.81 \mathrm{ml}$ per day per $200 \mathrm{~g}$ of rat weight. This dosage was obtained from a conversion factor of 0.018 on the basis of human weight of $70 \mathrm{~kg}$ (Harmita and Maksum, 2005) supplemented with 1 table spoon VCO or MG 3 times a day, equivalent to $45 \mathrm{ml}$ per day. Both the positive and negative control groups were not administered orally neither with VCO nor coconut cooking oil and were administered orally with $1 \mathrm{ml}$ drinking water (irrespective of the rat weight).

\subsection{Observation and analysis}

During the research, every 4 days theirs blood glucose levels of the rats in each group were observed from each tail using a Glucometer instrument (Henry, 2002). The blood withdrawn from each rats tail using syringe of Glucometer. The drop of blood from the tail swab to the test strips apparatus of glucometer (Allmedicus, USA). At the end of the research on the $29^{\text {th }}$ observation day all the rats were sacrificed, and their cholesterol, LDL and HDL level of the blood obtained from their heart organ were analyzed. In addition, at the end of treatment, the following activities were performed : the sampling of pancreas organ, fixation, dehydration, clearing, paraffin infiltration, embedding, sectioning, staining, mounting, and making photomicrograph.

\subsection{Research place}

The research was conducted at Laboratory of Animal Experiment, Department of Food Science and Technology, Faculty of Agricultural Technology and SEAFAST Center (South East Asia Food and Agriculture Science and Technology) Bogor Agricultural University, Laboratory of Histology Faculty of Veterinary Medicine, Bogor Agricultural University, and at the Center for Agro-Based Industries (CABI) Ministry of Industry, Bogor Indonesia.

\subsection{Statistical analysis}

Experimental Design of the research was Completed Randomize Design. If the treatment effect was significant, continuous test was then conducted using LSD (Least Significant Difference) or Duncan at $\mathrm{p}$ value $5 \%$ or $1 \%$ significant level. Statistical analysis was done using software SPSS 13.

\section{Result and Discussion}

\subsection{Serum blood glucose level}

After alloxan treatment, except for the negative group of rats (the healthy rat group), the rest of the rat groups condition of baseline had serum blood glucose level more than $200 \mathrm{mg} / \mathrm{dl}$ categorized as suffered from diabetic mellitus. All 5 groups of rat were fed with basic feed and drinking water every day ad libitum. In addition, VCO and coconut cooking oil were administered orally to each group of the rats every day.

Figure 1 shows that the average value of serum blood glucose levels for the $\mathrm{K}+$ (Positive Control) rat groups and MG rat groups (the rats fed by coconut cooking oil) tend to be higher than the other rat groups, since the positive control group were conditioned to suffer from diabetes and no treatment for diabetic. Although statistically no significant different, the blood glucose levels MG rat groups (rats treated with the coconut cooking oil) decreased, with the decreasing value was smaller than that of other groups treated with VCO (VA and VB rat groups), may be caused by the manufacturing process of coconut cooking oil which uses high temperature and chemicals. 


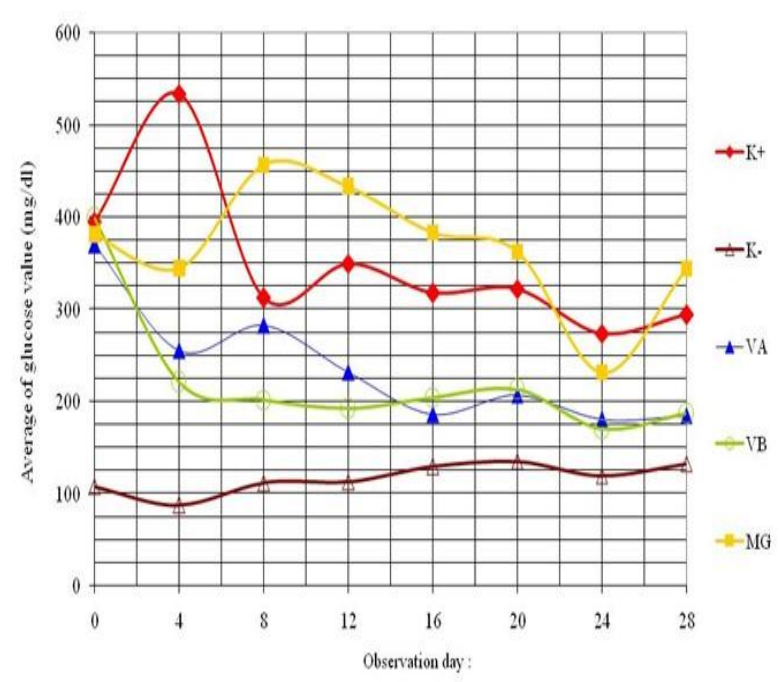

Figure 1. The Average of Serum Blood Glucose Level of Rats

There were no significant difference of serum blood glucose level among all group of treatments, but Spearman's rho correlation analysis shows that compared to other rat groups, VA rat group has the most closely correlated in lowering blood glucose of diabetic rats. The data show that the correlation value of VA rats group is -0.929 which means that during the observation time, glucose levels decreased very closely and significantly different at $1 \%$ level. Meanwhile VB rat group had a correlation value of -0.762 and significantly different at $5 \%$ level. The result shows that the application of heat in the production process of VCO has a significant different effect on the activities of bioactive compound fatty acids in lowering blood glucose levels of diabetic rats.

Fife (2001) stated that the Medium Chain Fatty Acids (MCFA) in coconut oil has small enough molecular weight to enter the cell without the help of the insulin hormone. In other words MCFA can enter the cells regardless the existence of insulin or even if the cell is insulin resistant. Further, Garfinkel et al. (1992) and Han et al (2003) explained that coconut oil can help regulate blood sugar, because the bioactive compound contained is the MCFA which can increase insulin production and sensitivity. In line with the above findings, Opara et al (1994) stated that Lauric acid as a MCFA is fatty acids that increase the highest percentage basal insulin output compared to the short or long chain fatty acids.

\subsection{Blood serum cholesterol}

Figure 2 shows that total cholesterol value of all rats was below of the danger threshold. The safe threshold for total cholesterol is $<200 \mathrm{mg} / \mathrm{dl}$ (Henry, 2002 and American Diabetes Asociation, 2004). This

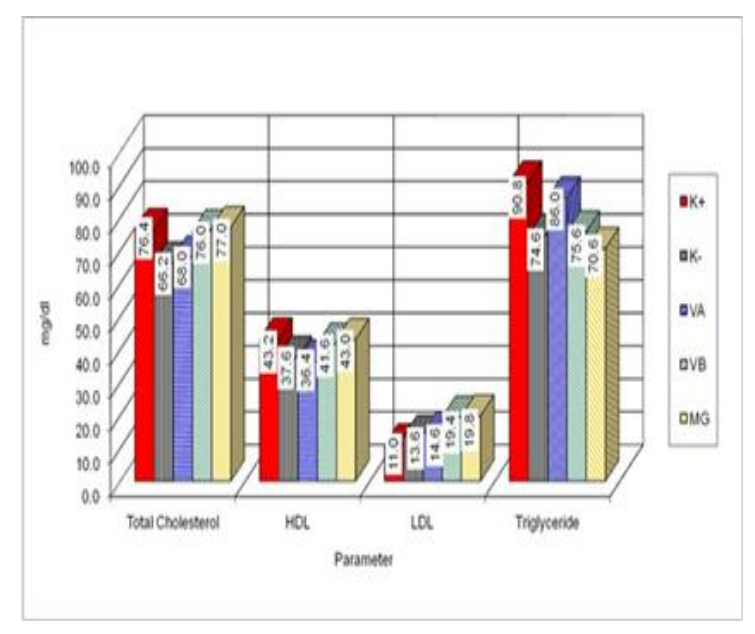

Figure 2. Serum Cholesterol Level in Each Group of Rats.

is in accordance with the statement of Rethinam and Bosco (2006), that medium chain saturated fatty acid did not increase blood cholesterol.

Figure 2 indicates that VCO treatments (VA and VB rat groups) relatively did not alter the levels of total cholesterol, HDL, LDL and triglycerides of diabetic mellitus rat blood serum compared to those of the $\mathrm{K}+$ rat group. The European Task Force on Coronary Prevention recommends for decreasing the total cholesterol $<190 \mathrm{mg} / \mathrm{dl}$ and LDL i.e. $<115$ mg / dl (Henry, 2002). Research data as showed in Figure 2, that the total cholesterol of $\mathrm{K}+$ rat group is 76.4 while the VA and VB rats groups were 68.0 and 76.0 , respectively, means that 28 days consumption did not increase levels of total cholesterol of diabetic rats.

According to Henry (2002) low concentrations of HDL <39 mg / dl for men and <43 for women, especially when associated with fasting triglyceride values $>180 \mathrm{mg} / \mathrm{dl}$, estimated to be at high risk for coronary heart disease. Based on Figure 2, the levels of HDL cholesterol and triglycerides of the VCO treated rat groups (VA and VB rat groups) are on safe threshold. This result in line with the study of Rethinam and Bosco (2006) that stated fatty acids of the VCO are rapidly absorbed by the rat's body do not deteriorate the rat's body lipid.

Figure 2 shows that VCO consumption in VA and VB compared to control positive group. However, the increased LDL value was still below the threshold. The European Task Force on Coronary Prevention recommends for lowering total cholesterol i.e. $<190 \mathrm{mg} / \mathrm{dl}$ and LDL i.e. $<115 \mathrm{mg} /$ dl. Meanwhile, according to the American Diabetes Association (2004) normal LDL value was <160 mg / dl (Henry, 2002).

Likewise, Figure 2 shows that the $\mathrm{K}+$ rat group or untreated diabetic rats, has higher triglyceride value than VA, VB and MG groups. This shows that the triglyceride value of $\mathrm{K}+$ rats group i.e. 153.6 can be 
reduced by the VCO treatment. The triglyceride value of the treated VA and VB rat groups are 86 and 75.6 respectively. In other words VCO did not increase the value of blood triglycerides of diabetic rats. As previously mentioned, this happens because of VCO can be quickly absorbed by the body, converted into energy, and is not stored as body fat, therefore the VCO did not affect the condition of the body lipids (Rethinam and Bosco, 2006).

Based on the results of this research, it was found that during the 28 days-observation the VCO orally fed to the diabetic rats did not significantly increased triglyceride values. Similar study conducted by Rajamohan (1997), shows that coconut oil consumption provides the total cholesterol and triglycerides lower than that of peanut oil.

\subsection{Profile of pancreatic organ}

Haematoxylin-Eosin (HE) tinting was conducted to see in a qualitative way the general morphology of pancreatic tissue of rats. This tinting composed of two color components, haematoxylin and Eosin. Haematoxylin is an alkaline dye, colored the acidic cell nucleus whereas Eosin is an acidic dye colored the alkaline cytoplasm (Banks 1993). The observed parameters of HE tinting in the preparations of the pancreas is a general morphology of pancreatic tissue and the number of Langerhans island. The pancreatic organ tissues of $\mathrm{K}+$ and $\mathrm{MG}$ rat groups showed the number of degenerating and necrotizing of acinar cells, higher than VA and VB rat groups. The pancreatic organ tissue of VA and VB rat groups have only a very few number of degenerating and necrotizing acinar cells as shown in Figure 3.

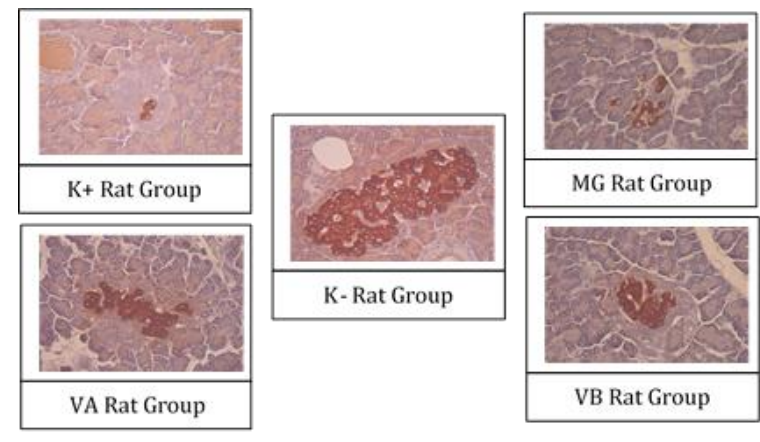

Figure 3. The Acinar Cells of Pancreatic Organ of Each Rat Group

The counting results of the pancreatic tissue's Langerhans islands of rat groups per five fields of view are presented in Table 1.
Table 1.

The average number of langerhans islands of pancreatic tissues of each rat group with $\times 20$ magnification

\begin{tabular}{ll}
\hline Rats Group & The Number of Langerhans Island (unit) \\
\hline K(-) & $3.40 \pm 1.18^{\mathrm{b}}$ \\
$\mathrm{K}(+)$ & $1.40 \pm 1.06^{\mathrm{a}}$ \\
$\mathrm{VA}$ & $2.13 \pm 1.46^{\mathrm{a}}$ \\
$\mathrm{VB}$ & $1.93 \pm 2.12^{\mathrm{a}}$ \\
MG & $1.53 \pm 1.18^{\mathrm{a}}$ \\
\hline
\end{tabular}

Remark: The Different Superscript on the SameColumnIndicated The Significant Different $(\mathrm{p}<0.05)$

Based on statistical analysis of Variant (ANNOVA), the number of Langerhans islands of the $\mathrm{K}$ - rat group was significantly higher ( $p<0.05)$ compared to other rat groups, since this group is healthy rats. While the $\mathrm{K}+, \mathrm{VA}, \mathrm{VB}$, and $\mathrm{MG}$ groups have no significant difference in Langerhans islands number among the groups, as shown by stable number of Langerhans islands during 28 days. Yet the number of Langerhans islands cannot describe the damage of pancreatic tissues and cells in them. These tissues and cells cannot be detected by haematoxylin-Eosin tinting (HE). Therefore, it needs advanced tinting by using immuno histochemical to detect the $ß$ cells within the Langerhans islands. The results of $\beta$ cell counting of the pancreatic tissues of rats within the Langerhans islands per three fields of view are presented in Table 2.

Table 2.

The average number of $\beta$ cells of pancr eatic tissues inlangerhans islands with $\times 20$ magnification

\begin{tabular}{lc}
\hline Rat Groups & $\begin{array}{c}\text { The Number of } \beta \text { Cells in Langerhans Islands } \\
\text { (Unit) }\end{array}$ \\
\hline $\mathrm{K}(-)$ & $63.44 \pm 15.29^{\mathrm{c}}$ \\
$\mathrm{K}(+)$ & $10.11 \pm 6.5^{\mathrm{a}}$ \\
$\mathrm{VA}$ & $22.78 \pm 7.03^{\mathrm{b}}$ \\
$\mathrm{VB}$ & $18.89 \pm 8.27^{\mathrm{b}}$ \\
$\mathrm{MG}$ & $8.67 \pm 3.12^{\mathrm{a}}$ \\
\hline
\end{tabular}

Remark: TheDifferent Superscript on the Same Column Indicates the Significant Difference $(\mathrm{p}<0.05$

Observations of the $\beta$ cells were quantified by counting the number of $\beta$ cells in each rat pancreas. $\beta$ cells detected by immune histochemical staining were indicated by the dark brown color in the Langerhans island cells, while others were blue. The blue color comes from the counter staining by using haematoxylin dye which colors the pancreas cells.

The results of statistical analysis show that the number of $\beta$ cells of Pancreatic tissues of VA and VB groups is significantly higher $(p<0.05)$ than those of group $\mathrm{K}(+)$ and group $\mathrm{MG}$ rats although it is significantly lower $(p<0.05)$ than that of the group $K$ $(-)$ rats.

Diabetes mellitus causes a situation in which the body cannot control blood glucose levels due to the disruption of insulin secretion by $\beta$ cells in the pancreatic tissues of Langerhans islands. The process of glucose metabolism is very important to 
generate energy for the survival of cells in the body. However, diabetes mellitus makes the body cells unable to metabolize glucose so the body suffers from energy shortage. Consequently, the body looks for alternative energy through Glycogenolysis and gluconeogenesis. Both processes produce byproducts of free radicals that can cause damage to the body's cells including pancreatic cells. Alloxan is one of the substances for inducing experimental diabetes mellitus which selectively destroys pancreatic $\beta$ cells (Walde et al. 2002). Diabetes mellitus suffered by rats in this study was due to the damaged pancreatic $\beta$ cells induced by Alloxan which results in the decreased insulin secretion. According to Szkudelski (2001), Alloxan damages pancreatic $\beta$ cell through the formation of reactive oxygen species preceded by the reduction of Alloxan. Alloxan reacts with reducing agents such as cysteine and enzymes belonging to an SH-group. SHglucokinase is an enzyme that plays an important role in insulin secretion, therefore, Alloxan has a high affinity for the glucokinase enzyme. Alloxan reacts with two SH-groups of the glucokinase enzyme to form a dimeric bond which inactivates the enzyme and disturbs the insulin secretion. Eventually it damages $\beta$ cells and results in the state of diabetes.

Alloxan is also the free radicals that can damage biomacromolecules such as lipids, phospholipids, and carbohydrates that are the components of cell walls (Lenzen 2007), and the DNA inside the nucleus. The DNA in the nucleus was also attacked by free radicals. If DNA damage is not too much, it can be improved. However, the recovery process often causes cell mutation which can eventually become cancer (Aruoma 1998). General morphology of pancreatic tissue and cell damage inside acinar cells and the number of Langerhans islands can be seen by haematoxylin-Eosin tinting (HE). The pancreatic tissues of group $\mathrm{K}(-)$ has the least amount of acinar cell degeneration and nekrosa but has the highest number of Langerhans islands compared with other treatment groups. This is because pancreatic tissues of treatment group $\mathrm{K}(-)$ are not induced by Alloxan, thus diabetic condition does not appear. Meanwhile the pancreatic tissues of the treatment group $\mathrm{K}(+)$ has a higher number of degenerated acinar cells to nekrosa compared with the treatment groups of VA and VB. It is because the pancreatic tissues of treatment group $\mathrm{K}(+)$ are induced by Alloxan and merely fed with water so the acinar cells deteriorate quickly.

Pancreatic tissues of group VA and VB have fewer acinar cells degenerating to nekrosa compared with the $\mathrm{K}(+)$ and $\mathrm{MG}$, because the pancreas of group VA and VB induced by Alloxan receive VCO intake from the body, so the rate of damaged cells can be inhibited. VCO contains Lauric Acids, a medium chain saturated fatty acids, which have been reported to increase insulin secretion (Garfinkel et al 1992). Increased secretion of insulin causes the search for glucose alternatives to be reduced which results in fewer by products of free radicals. The rate of cell damages in pancreatic tissue group VA and VB can be inhibited so that the amount of cell damage becomes fewer than the group $\mathrm{K}(+)$ and MG. With $\mathrm{HE}$ tinting, the number of Langerhans islands is not significantly different among group $\mathrm{K}(+), \mathrm{VA}, \mathrm{VB}$, and MG. To be able to detect $\beta$ cells contained in the Langerhans islands, the advanced colouring is done with immunohistochemical techniques. $\beta$ Cell detection in immunohistochemical may indicate a $\beta$ cell damage in diabetes mellitus condition. Pancreatic tissues of group $\mathrm{K}(+)$ has the least amount of $\beta$ Cell compared with other groups, this is because the pancreatic tissues of $\mathrm{K}(+)$ were induced by Alloxan and treated with drinking water only resulting in the high rates of $\beta$ cellular damages while the insulin secretion becomes very low. Reduction of insulin secretion that occurs in $\beta$ cells of group $\mathrm{K}(+)$ was caused by Alloxan which inactivated the glucokinase enzyme. Glucokinase is an enzyme-with SH group which has an important role in the secretion of insulin in the pancreas. Alloxan has a high affinity with proteins having-SH groups, therefore, Alloxan reacts with the two SHgroups of glucokinase which results in the dimer bond causing the inactivation of enzymes and being responsible for the $\beta$ cell decay (Szkudelski 2001). In addition, Alloxan also reduces ATP production, causing the opening of $\mathrm{K}+$ channels and the plasma membrane hyperpolarization. Then, it was followed by the closing of the gate voltage that causes $\mathrm{Ca} 2+$ $\mathrm{Ca} 2+$ concentration decrease resulting in decreased secretion of insulin and cell decay (Drews et al. 2000).

In the MG treatment group, the number of $\beta$ cells produced was not much different from that of the $\mathrm{K}$ (+). In a diabetic condition, the search for glucose alternatives produces by products of free radicals. The high amount of free radicals due to the diabetic condition will increase further with the consumption of cooking oil containing a few unsaturated fatty acids that will increase lipid oxidation, which will also produce by products of free radicals. As a result, the free radicals present in the pancreas of MG treatment group will be even higher. This will eventually make the function of $\beta$ cells of the pancreas decrease causing the reduced insulin secretion which will make the faster rate of $\beta$ cells decay in pancreatic tissues of MG treatment group faster. Consequently, the number of $\beta$ cells becomes fewer. Pancreatic tissues of treatment group VA and VB have higher amount of $\beta$ cells than that of the treatment group $\mathrm{K}(+)$ and $\mathrm{MG}$. It indicates that there is an inhibition of the rate of 
damage to the Langerhans island of $\beta$ cells in the treatment group VA and VB. The secretion of insulin in the group VA and VB is triggered by the increased concentration of intracellular $\mathrm{Ca} 2+$ released by the gate voltage of $\mathrm{Ca} 2+$ channels within the $\beta$ cell plasma membrane. The medium chain saturated fatty acids play an important role in the activation of the $\mathrm{Ca} 2$ + channel resulting in mobilization of intracellular $\mathrm{Ca} 2+$ that triggers the release of insulin from $\beta$ cells (Gravena et al. 2002). The saturated fatty acids that play an important role in stimulating insulin secretion is Lauric acid, palmitic acid, and capric acid contained in the VCO (Garfinkel et al. 1992). Increased secretion of insulin causes the search for glucose alternatives to be reduced, and the by product of free radicals produced is less. Thus $\beta$ cells damage can be inhibited and the number of $\beta$ cells present in the pancreas of treatment group VA and VB is higher than that of $\mathrm{K}(+)$ and MG. However, the number of $\beta$ cells in the pancreas of the treatment group VA and VB is still less than that of the treatment group $\mathrm{K}(-)$. It is because pancreatic tissues of treatment group $\mathrm{K}(-)$ are not induced by Alloxan.

As diabetic condition did not arise in this group, the number of $\beta$ cells remains intact. In addition to medium chain saturated fatty acids, VCO also contains vitamin E and antioxidants. Antioxidants contained in VCO can neutralize free radicals that accumulate in cells due to diabetes mellitus so $\beta$ cell damage caused by free radicals can be inhibited.

\section{Conclusion}

Non heated and controlled heated VCO showed no significant effect on lowering blood glucose level, but on lowering blood glucose, VCO A (without heat) has closer correlation and very significant difference $(-0.929$ correlation value at $\mathrm{p}<1 \%)$, compared to VCO B (controlled heat) (correlation value of -0.762 , at $\mathrm{p}<5 \%$ ) and coconut cooking oil ( -0.524 correlation value at $\mathrm{p}>5 \%$ )

Non heated VCO (VA) showed significant positive correlation with blood glucose level $(-0.929$ correlation value at $\mathrm{p}<1 \%$ ), while controlled heated VCO (VB) significantly different at p 5\% level but coconut cooking oil could not lowering the blood glucose level.

VCO and coconut cooking oil showed no significant effects on raising the level of total cholesterol, HDL value, LDL value and serum triglyceride of diabetic mellitus rats at p 5\% level.

The virgin coconut oil significantly inhabited cell damage of pancreatic tissue on the Langerhans island of diabetic mellitus rats.

\section{Acknowledgement}

This research was supported by Center for AgroBased Industry (CABI), we would like to convey our gratitude to the Director of CABI for sharing his pearls of wisdom with us during the study and conducting the research. We are also immensely grateful to Mr. Adi the animal laboratory technician from the Bogor Agricultural University for his assistant on preparing the rats on doing the research.

\section{Reference}

Anonim. 2006. Teknologi Sel Induk Harapan Baru Bagi Diabetesi.http://www.republika.co.id/Minggu 10 Desember 2006. (Diakses tanggal 21 Januari 2007).

Aruoma OI.1998. Free radicals, oxidative stress, and antioxidants in human health and disease. J.AOCS 75(2)199-212.

Banks WJ. 1993. Applied Veterinary Histology 3rd ed. USA : Mosby. pp 6.

[BSN] Badan Standardisasi Nasional. 2002. SNI 01-3741-2002 Minyak Goreng. BSN. Jakarta. 2008. SNI 7381- 2008 Minyak Kelapa Virgin (Virgin Coconut Oil). BSN. Jakarta.

Codex. 2001. Codex Standard for Edible Fats and Oils Not Covered by Individual Standards. Codex Stan 19-1981 (Rev.21999). Codex Alimentarius. Vol 8 - 2001.

Dayrit, C.S.2005. The Truth About Coconut Oil The Drughstorein a Bottle. Anvil Publishing, Inc. Pasig City Philippines.

Drews G, Kramer C, Dufer M, Krippeit P. 2000. Contrasting effects of alloxan on islets and single mous epancreatic $\beta$ cells. J Biochem 352: 389-397.

Enig, M.G. 1996. Health and Nutrition Benefits from Coconut Oil : an Important Functional Food for 21st Century. http:www.westonaprice.org/know_your_fats/. (Diakses tanggal 2 Oktober 2007).

Fife, B.N.D. 2001. The Healing Miracle of Coconut Oil. Colorado, USA. Colorado Springs.

Garfinkel M, Steve L, Emmanuel C.O, and Onye E.A. 1992. "Insulinotropic potency of lauric acid: a metabolic rational for medium chain fatty acids (MCF) in TPN formulation". Journal of Surgical Research. Volume 52 Issue 4 : 328-333. www.sciencedirect.com. (Diakses tanggal 25 April 2007).

Gravena C, Mathias PC, Ashcroft SJ. 2002. Acute effects of fatty acids on insulin secretion from rat and human islets of Langerhans. Journal of Endocrinology 173(1):73-80.

Han, Jianrong., Hamilton, J.A., Kirkland, J.L., Corkey, B.E. and Guo, W. 2003. "Medium chain oil reduces fat mass and down regulates expression of adipogenic genes in rats". Obesity Research Vol 11 No. 6: 734 - 744.

Harmita dan Maksum Radji. 2005. Buku Ajar Analisis Hayati.Edisi Ke 2, Cetakan ke 2. Departemen Farmasi FMIPA, Universitas Indonesia, Depok.

Henry, J.B. 2002. Clinical Diagnosis and Management by Labolatory Method. 20th ed. W.B. Founder CO. Philadelpia.

Kabara, J.J. 2000. "Nutritional and health Aspect of Cococnut Oil". Proceedings of the 37 COCOTECH Meeting / ICC 2000, 24 - 28July 2000, Chenai India. Penerbit APCC. Jakarta.

Kirk-Othmer. 1965. Encyclopedia of Chemical Technology. 2nd ed. Vol.8. John Wiley and Sons. Inc. New York. USA

Lawless, H.T. 1998. Sensory Evaluation of Food, Principle and Practices. New York. Chapman and Hall.

Lenzen S. 2007. The mechanisms of alloxan- and streptozotocininduced diabetes. In: Diabetologia 51(2) : 216-226. 
Halaman | 98

O’Brien, Richard D. 1998. Fats and Oils; Formulating and Processing for Applications. Technomic Publishing Company, Inc. Pennsylvania. USA. P. 667.

Opara, C. Emmanuel., Marc Garfinkel, Van S. Hubbard, Warner M. Burch, and OnyeE. Akwari. 1994."Effect of Fatty Acids on Insulin Release : Role of Chain Length and Degreeof Unsaturation". American Journal Physiology. 266 (Endocrinol. Mrtab. 29) : E635-E639. http//ajpendo.physiology.org. (Diakses tanggal 27 November 2007).

PERKENI. 2002. Petunjuk Praktis Pengelolaan Diabetes Mellitus Tipe 2. PB. PERKENI. Jakarta.

Rajamohan, T. 1997. Study on the Effect of Consumption of Coconut kernel and Coconut Oil on the Serum Lipid Profile. Coconut Development Board, Kochi, India.

Rethinam, P., Singh S.P. and Muhartoyo. 2005. Coconut Oil for Health and Nutrition. Jakarta. Asian and Pacific Coconut Community.

Rethinam, P. and Bosco S.J.B. 2006. Coconut Harvest, Processing and Products. Asian and Pacific Coconut Community. Jakarta.

Rindengan, Barlina dan Hengky Novarianto. 2005. Pembuatan dan Pemanfaatan Minyak Kelapa Murni. Jakarta. Penebar Swadaya.

Supriatna Dadang, Guring Pohan, Bakri Rosidi, Dedi Kusmayadi, Irwan Sutiarna. 2000. Pengembangan Proses Pembuatan Minyak Kelapa Metode Pengepresan Semi Basah.Laporan Proyek DIP.Bogor.Balai Besar Industri Agro, Departemen Perindustrian.

Szkudelski T. 2001. The mechanisms of alloxan and streptozotosin action in B cells of rat pancreas. J Physiol Res 50(6): 537-546.

Tillekeratne, H.A., Ranasinghe, A.T., Abeywichcrama, L.D. and Joseph, P.G. 1998. Common Fund for Commodities Project : Intermediate Moisture Content (IMC) Technlogy, Sri Lanka : Sub-Objective 2.2. CDA Sri Lanka. CFC Report No. 82.

Walde SS, Dohle C, Schott-Ohly P, Gleichmann H. 2002. Molecular target structure in alloxan-induced diabetes in mice. Journal of Life Sciences 71(14): 1681-1694.

Wibowo Susilo. 2005. Peran V.C.O. Untuk Kesehatan dan Pencegahan Komplikasi Diabetes. Makalah disampaikan pada Workshop dan Pameran "Penggalian Aplikasi dan Aspek Komersial Sumber Daya Alam Indonesia (Batu Mulia, Atsiri dan VCO). Jakarta. Deputi Perkembangan Ristek IPTEK Kementrian Negara Ristek. 